for it. Existing theories appear to be inadequate, and further work is necessary.

The protection of rubber from deterioration, the preservation of hydrogen peroxide from decomposition and the prevention of metallic corrosion are also considered in this book. The function of retarders in the setting of plaster-of-Paris and cement is also discussed.

In the last portion, the decomposition of numerous organic and inorganic compounds, the reactions of halogens with hydrogen and other reducing agents and the retardation by water in the processes of esterification, saponification, hydrolysis and the decomposition of organic substances by concentrated sulphuric acid, have been summarized. A brief account of the quenching of fluorescence and the after-glow of active nitrogen has also been included. There is a bibliography of 1,630 original papers at the end of the book.

The subject-matter of this book is of considerable practical and theoretical importance. Prof. Bailey's discussion of the diverse topics involved is clear and exhaustive, and presented in a very readable form. The book should be valued and widely read.
N. R. DHAR.

\title{
Reflections on Life
}

Life Here and Now :

Conclusions Derived from an Examination of the Sense of Duration. By Arthur Ponsonby (Lord Ponsonby of Shulbrede.) Pp. 289. (London : George Allen and Unwin, Ltd., 1936.) 10s. 6d. net.

$\mathrm{T}$ HIS rather unusual book of reflections on life not only gives us in effect an interesting portrait of one of our greatest authorities on the type of data which characterize the 'commonplace book', but also an unexpected plea for individual action in support of high ideals, whether of peace or of social reform. Lord Ponsonby has long been occupied with thought on the nature of time and on our appreciation of its meaning and value in the art of living. He now advances a general argument based on an analysis of the sense of duration, and relying on the scientific attitude of Huxley's generation, he tilts valiently at organized religion as he conceives it. The idea of personal immortality is challenged, and its rejection appears to be inspired largely by his contention that too much time is occupied in vain speculations about the future to the neglect of the present.

If Lord Ponsonby appears to overstress the logical part of man's nature, there is nothing in this finely written plea for more effective use of the immediate moment to control the duration of our living which can possibly impede that rapprochement between science and religion for which Smuts and others have been pleading. Not even those whose convictions he brushes on one sidenot always on the most convincing grounds-can fail to recognize the dignity and sincerity of his plea for a better use of our present term, of the proper use of the new in the here, of the moment as it passes in our own environment. He gives us wise words on the small matters which make up the art of living, but most will welcome the book for its inspiring idealism. Planning the future, he claims, is better for the mind than analysing the past, and if he is impatient with creeds it is perhaps mainly in so far as they impede progress.

Lord Ponsonby believes in individuality, and nowhere is this clearer than in his plea for a courageous stand for peace. "Our forefathers certainly would be unable to discover any element of glory in modern warfare; but they would observe in the world a noticeable depreciation of the value of human life." The warm human sympathies of the writer are as conspicuous as the sincerity of his thought and the lucidity of his diction, and they lead him to a final plea for action and service which is poles asunder from the frenzied plea of the demagogue to "do something". Its calm and dignified courage should win the sympathy of all who appreciate the inspiring personality imprinted upon that plea: "Now is the greatest of moments, the most real thing of which we can be aware. . . . To seize it as an opportunity means bracing ourselves up for action, decision, bite, endeavour ... not vague resolutions but insistent occupation, not irresolute hopes but intent purposes, not languid aspirations but ready service, not 'Time will tell', but 'I will tell Time' . . . the errors of impetuosity are far less serious than the errors of caution and indolence and the enervating paralysis of procrastination. ... There is no failure except in leaving off trying."

These are no pages from a dilettante's notebook, but a glimpse into the soul of one who has made time his servant, and himself compelled the hours to suit his intentions, the minutes to serve his purpose.

\section{R. Brightman.}

